\title{
Main factors of influence on accounting procedures in Slovenian business enterprises
}

\section{Introduction}

Like other human activities and disciplines, accounting is largely a product of its environment. The environment of accounting consists of social, economic, political and legal conditions, restraints and influences that vary from time to time. The result is that accounting objectives and practices constantly change and thus differ among different countries.

Accounting may best be defined by describing the three essential characteristics of accounting (Kieso et al, 2005: 2):

1. identification, measurement and communication of financial information about

2. economic entities to

3. interested users.

Thus, we could say that accounting is a service activity. Its function is to provide quantitative information, primarily financial in nature, about economic entities that is intended to be useful in making both economic decisions and resolved choices between alternative courses of action. ${ }^{1}$

Many individuals mistakenly consider book-keeping and accounting to be the same. This confusion is understandable because the accounting process includes the book-keeping function. However, accounting also includes much more. Book-keeping usually involves only the recording of economic events and it is, therefore, just one part of the accounting process. In total, accounting involves the entire process of identifying, recording and communicating economic events (Weygandt et al, 2002: 6).

\section{Financial and management accounting}

Accounting may be further divided into financial accounting and management or managerial accounting. Financial accounting is the branch of accounting that provides economic and financial information for investors, creditors and other external users, while management accounting is the branch of accounting that provides economic and financial information for managers and other internal users. Table 1 provides an overview of the basic features of financial and management accounting and illustrates the contrast between them.

1 Accounting Principles Board, Statement No 4: 'Basic Concepts and Accounting Principles Underlying Financial Statements of Business Enterprises', paragraph 40, in Alexander and Nobes, 2001: 4. 
Table 1 - Basic features of financial and management accounting

\begin{tabular}{|c|c|c|}
\hline & Financial accounting & Management accounting \\
\hline Audience & $\begin{array}{l}\text { External: shareholders, creditors, tax } \\
\text { authorities }\end{array}$ & $\begin{array}{l}\text { Internal: workers, managers, } \\
\text { executives }\end{array}$ \\
\hline Purpose & $\begin{array}{l}\text { Report of past performance to } \\
\text { external parties; contracts with } \\
\text { owners and lenders }\end{array}$ & $\begin{array}{l}\text { Information for internal decisions } \\
\text { made by employees and managers; } \\
\text { feedback and control on operating } \\
\text { performance }\end{array}$ \\
\hline Timeliness & Delayed; historical & Current, future-oriented \\
\hline Restrictions & $\begin{array}{l}\text { Regulated; rules driven by generally- } \\
\text { accepted accounting principles and } \\
\text { government authorities }\end{array}$ & $\begin{array}{l}\text { No regulations; systems and infor- } \\
\text { mation determined by management } \\
\text { to meet strategic and operational } \\
\text { needs }\end{array}$ \\
\hline $\begin{array}{l}\text { Type of } \\
\text { information }\end{array}$ & Financial measurements only & $\begin{array}{l}\text { Financial plus operational and } \\
\text { physical measurements on processes, } \\
\text { technologies, suppliers, customers } \\
\text { and competitors }\end{array}$ \\
\hline $\begin{array}{l}\text { Nature of } \\
\text { information }\end{array}$ & $\begin{array}{l}\text { Objective, auditable, reliable, } \\
\text { consistent, precise }\end{array}$ & $\begin{array}{l}\text { More subjective and judgmental; } \\
\text { valid, relevant, accurate }\end{array}$ \\
\hline Scope & $\begin{array}{l}\text { Highly aggregated; report on entire } \\
\text { organisation }\end{array}$ & $\begin{array}{l}\text { Disaggregated; information for local } \\
\text { decisions and actions }\end{array}$ \\
\hline
\end{tabular}

Source: Atkinson et al, 2003: 6

Management accounting can be carried out on the basis that no information need be kept secret for commercial reasons and that the preparers will have no incentive to disguise the truth. This is because management is providing information to itself. So, the information does not need to be externally checked, i.e. audited. It can be more detailed and more frequent than for external financial reporting because there is no expense of external checking or publication. Also, the management will not want any biases, whereas some outside users may prefer a tendency to understate profits and values where there is uncertainty: management may be happy for many estimates about the future to be made which might be too subjective for external reporting. Indeed, some management accounting figures involve forecasting all the important figures for the next years in the form of budgets, whereas financial reporting concentrates on the immediate past. Another point is that there do not need to be any rules imposed on management accounting, because management can trust itself. By contrast, external financial reporting probably works best with some clear rules from outside to the enterprise in order to control management and to help towards the comparability of one enterprise with another (Alexander and Nobes, 2001: 6).

\section{The role of accounting}

Viewed broadly, accounting might be seen as serving three different purposes (Willson et al, 1999: 69): 
- financial reporting

- inventory valuation and

- performance evaluation.

The first is concerned principally with reporting the overall results of the operations and financial condition of the enterprise to internal and external users (Willson et al, 1999: 69).

The second application permits the proper allocation and assignment of costs and expenses to inventory and to costs of goods sold or other current costs (Willson et al, 1999: 69). Financial accounting rules require that we match costs with revenues to calculate profit, which is a business necessity for pursuing the basic goals of every profit-oriented business organisation: that shareholders maximise their wealth; that employees retain their jobs and increase their personal human capital ${ }^{2}$; and that creditors can be paid. Consequently, any unsold finished goods inventories or work in progress inventories will not be included in the cost of goods sold, which is matched against sales revenue during a given period. In an organisation that produces a wide range of different products it will be necessary, for inventory valuation purposes, to charge the cost to each individual product.

The total value of the inventories of completed products and work in progress, plus any unused raw materials, forms the basis for determining the inventory valuation to be deducted from the current period's costs when calculating profit. This total is also the basis for determining the inventory valuation for inclusion on the balance sheet. Costs are therefore traced to each individual job or product for financial accounting requirements, but most organisations also produce internal profit reports at monthly intervals and thus product costs are also required for periodic internal profit reporting (Drury, 2000: 15).

The third purpose permits the measurement of individual or group performance against predetermined goals. It facilitates the measurement of actual results against plan, budget or another selected standard and may apply to revenues, costs, margins, any other economic category or any particular combination of these. It involves the segregation of data according to the segment being reported on. It implies accountability by the segment of the business organisation; hence, the accounting process must identify those items that are considered 'controllable' by the segment, i.e. the centre.

2 Human capital is, together with structural capital, a constituent part of intellectual capital - the intangible assets of skill knowledge and information. Human capital is reflected in the knowledge and creativity of an organisation's personnel and is a source of strategic innovation and renewal. Human capital provides the foundation for the improvements that may, at least until adopted by others, provide the business organisation with a core competency. Without human capital, there would be few start-up business organisations with new products and/or services. Structural capital, such as information systems, knowledge of market channels and customer relationships, and management focus, allows human capital to be utilised (Raiborn et al, 1999: 9). However, in existing accounting systems, internally-developed intangibles are not accounted for, i.e. recognised in financial statements. Thus, many professional accountants and institutional investors believe that a new value-measurement framework is needed - new financial and management accounting concepts and practices so as to account meaningfully for the intellectual capital of a business organisation (Batchelor, 1999: 81). 
These responsibility centres may be of three types. Firstly, a responsibility centre may be a 'cost centre' if the supervisor is held responsible for costs only, i.e. the expenses of his department or the direct material or labour costs incurred. Secondly, a responsibility centre may broaden into a 'profit centre' if the supervisor is held accountable for a stipulated profit contribution. Thus, a given sales office or subsidiary or division might be a profit centre. And finally, if a manager is held responsible not only for profit results but also for the investment required to produce the margin or profit, then the responsibility centre is an 'investment centre'. It follows that the accounting accumulation and related reporting must follow organisational structure and the related functional responsibilities (Willson et al, 1999: 69).

Each of the purposes stated above may require a different presentation and reporting method. An ideal database for presentation and reports (sometimes called a data warehouse) is very detailed and cuts across business functions. Accountants combine or adjust these data to answer questions from particular internal or external users (Horngren et al, 2002: 2).

Prakash and Rappaport provide an interesting frame of reference, based on information flows, that shows the role of accounting in providing the kind of information that ties together the managerial process and links the business organisation to its environment. It shows the internal structure of the business organisation as composed of five information processes - planning; decision-making; implementation-cum-observation; data structuring, i.e. the accounting process; and performance evaluation which all interlink in such a way as to provide the necessary information to management.

It also shows the various information links of the firm to its environment, allowing:

a. the coupling of factor and product markets

b. external evaluation compliance

c. economic feedback and regulatory compliance.

The soundness of this frame of reference lies in its ability to show that the business organisation, in functioning as a system within the parameters determined by its environment, itself functions as an element in a higher-level system, namely the economy, wherein it interacts and interrelates with other elements and so takes part in the process of determining the very parameters within which it must function internally (Riahi-Belkaoui, 2004: 41). This frame of reference is shown in Figure 1. 


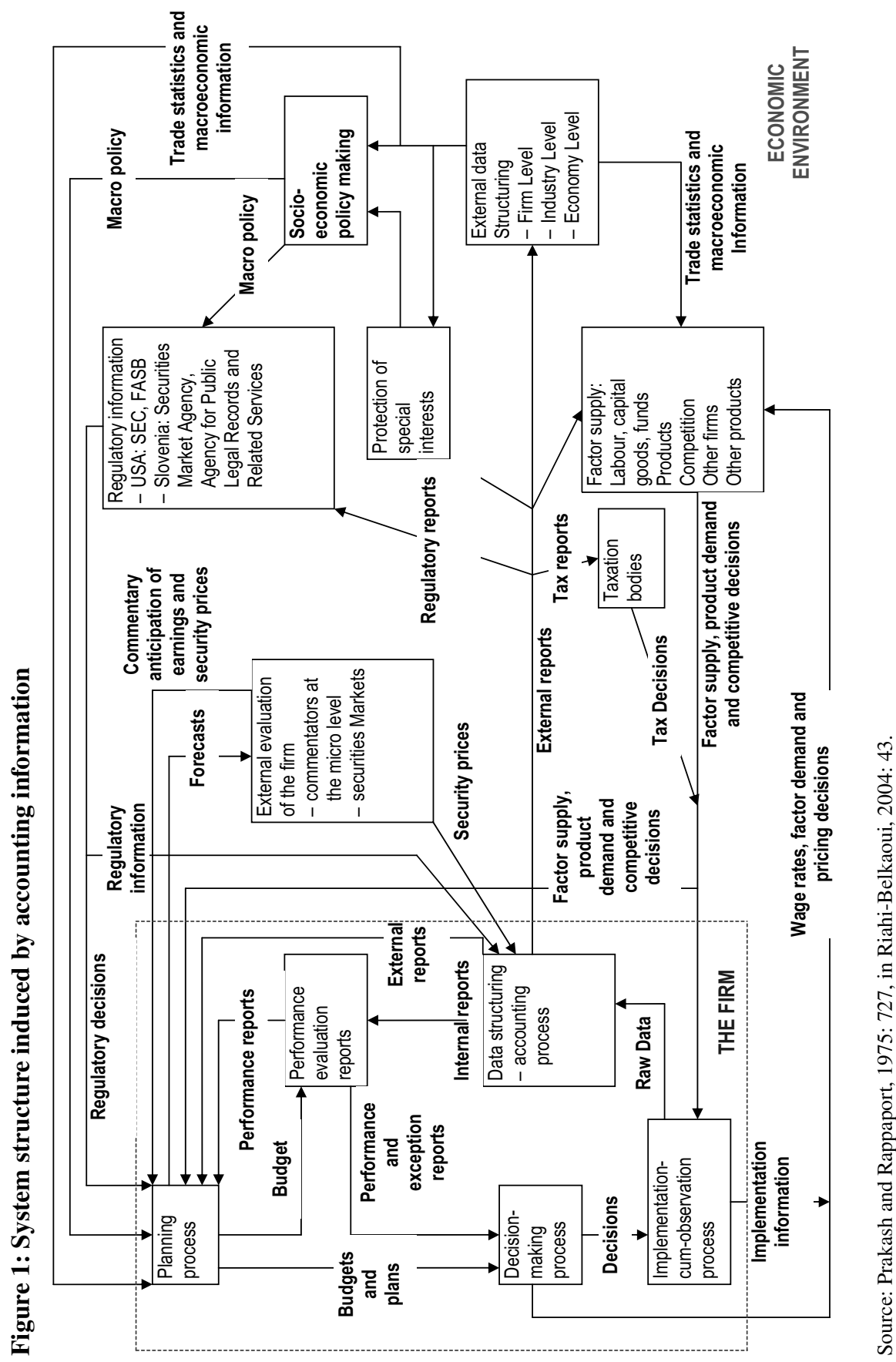




\section{Slovenian concept of accounting}

\section{Code of Accounting Principles}

The theoretical concept of Slovenian accounting is formally presented in the Code of Accounting Principles (hereinafter: the Code). This collection of professional solutions, which originates from the time of the former Yugoslavia, was last updated in 1995 by the Professional Council of the Slovenian Institute of Auditors.

These accounting principles were adopted mainly for the purpose of:

- helping professionals as a guidance and as an inspiration for their work

- promoting the diffusion of modern theoretical accounting accomplishments into practice

- setting up solid professional foundations for the elaboration of accounting standards. (Code, 1998: 3)

The Code consists of the following groups of principles:

I basic accounting principles

II principles of the presentation of economic categories

III principles of book-keeping

IV principles of budgeting

$\mathrm{V}$ principles of accounting supervising

VI principles of accounting analysis

VIIprinciples of accounting information reporting

VIIIprinciples of the organisation of the accounting department.

(Code, 1998: 3)

These principles basically examine the understanding of accounting and describe its fundamental features (Code, 1998: 4). If we compare these Slovene principles with the principles of other countries, we notice their very wide scope, which is due to the coverage of some accounting issues (especially Principles IV to VIII) which are usually not covered in other similar documents.

The Code is basically based on the Yugoslav model of accounting from 1964, where accounting is clearly separated from decision-making functions and business finance, and forms the core of the business organisation's information system, which can be seen in Figure 2. 
Figure 2 - Accounting functions embedded into information functions

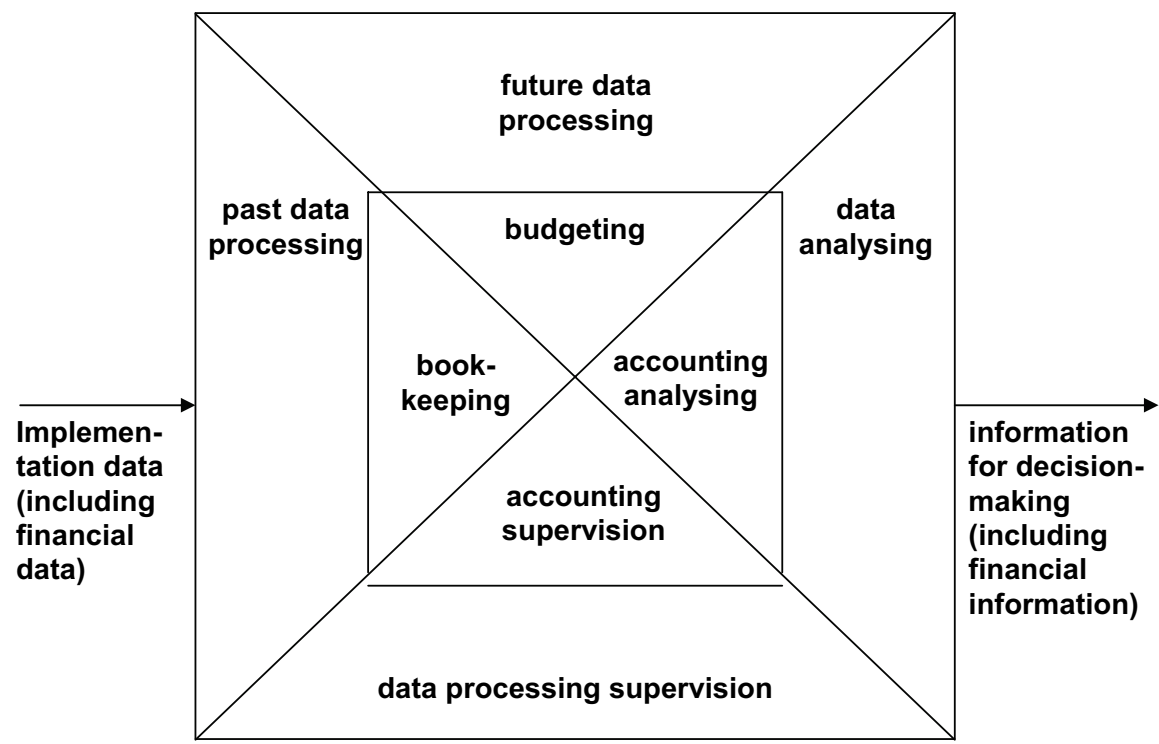

Source: Turk and Melavc, 2001: 19

Past (future) data processing is an information function which is composed of the collection, editing, initial transformation and then presentation of data regarding past (future) processes and states, and comprises, besides book-keeping, statistical recordkeeping and a part of operative record-keeping (Turk, 2002: 375).

The simplest definition of book-keeping would be that it is a process of the keeping of the books of account of a business organisation. Books of account are those linked books, records and files of data in which transactions are posted that are associated with assets, liabilities, revenues and expenses which are shown as entries in accounting records. Books of account are the result of an established accounting process of data editing and processing (Slovenian Accounting Standard (SAS) 22.1). Books of account are produced exclusively within book-keeping as a component of an accounting process. The keeping of the books of account represents merely the recording of actual economic categories and the changes therein, providing legal evidence in formal terms and which is based on book-keeping documents (SAS 22.2). Thus, we could say that book-keeping is a part of accounting that involves only the recording of economic events (Weygandt et al, 2002: 28). Books of account do not summarise all the actual categories. Instead, they represent a summary of those dimensions that can be expressed in terms of monetary units as well as those which, at the final level, give an insight into assets, liabilities, revenues and expenses expressed in terms of value both by individual types and in their entirety (SAS 22.3).

Books of account include two main books of account - the journal and the general ledger - as well as subsidiary books which are stipulated in internal accounting rules. 
The general ledger should be kept on the basis of the double entry book-keeping system (SAS 22.8).

Budgeting is the processing of information, expressed in a monetary unit that is relevant to the planned economic categories which appear within business processes and situations (SAS 20.1). The outputs of the budgeting process are different budgets. Budgets could be classified into business phenomena budgets; budgets prepared in respect of a group of business phenomena; budgets prepared in respect of organisational units; and budgets prepared in respect of an entire business organisation (SAS 20.18). The process of budgeting that comprises budgets significant to the entire business organisation, as well as its relations with others, is a component of the financial accounting system, whereas the process of budgeting that deals with detailed budgets covering the business organisation's internal activities is a component of the management accounting system (SAS 20.3).

Data analysing is an information function which comprises the analysing of the favourableness of the data which has already at least once been transformed and the formation of proposals for improvement, whereas accounting analysis deals with monetary data (Turk, 2002: 603).

Accounting analysing implies a process of accounting which is aimed at assessing the quality of phenomena and the accounting data relevant to them. It comprises analysis that is closely linked to the preparation of accounting reports on planned and implemented business processes and situations. It enhances the quality of accounting information, explains the situation within operations and the results achieved and thus provides the basis for improvements (SAS 29.1). Accounting analysing is a part of the overall analysis of a business organisation's activities (SAS 29.2). The process of analysing the variances between the actual amounts disclosed in statements of account and their relevant criteria takes into account the causes of those variances, which then represents the basis of their assessment and the search for possible solutions as well as the formulation of the appropriate actions to be taken (SAS 29.12). Examples of variances are those between the achieved and the budgeted financial results, i.e. revenues, costs, expenses, profits, cash flows, etc.

Data processing supervision is an information function which not only estimates the regularity of data formation and their transformation into information but also removes the irregularities. The main objects of supervision are all the other information functions, i.e. past data processing, future data processing and data analysing (Turk, 2000: 307).

Accounting supervision implies a process of the accounting-based assessment of the accuracy of phenomena and the accounting data relevant to them. It comprises a supervision of the process of the collection of the data that are subsequently included in the process of book-keeping or budgeting, as well as their processing and analysing; it also comprises the analysing and preparing of accounting reports on planned as well as actual business operations and situations.

Accounting supervision enhances the reliability of accounting information, which explains the situation within operations and the results achieved, thus providing the basis for improvements (SAS 28.1). Accounting supervision constitutes a part of the overall supervision of the activities of the business organisation (SAS 28.2). Accounting supervision is implemented in terms of the accounting-based control of data when 
these are entered and processed and in terms of the internal as well as external auditing of the accounting system (SAS 28.5).

The accounting control of data implies a process of the continued assessment of the accuracy of accounting data and the elimination of discovered irregularities. This work is done by the accounting department staff (SAS 28.21).

The internal auditing of an accounting system implies a subsequent assessment of the accuracy of the system of accounting data controls and the reliability of its operation. It is carried out by the internal audit department of a business organisation which should be separated from the business organisation's accounting department. Moreover, a business organisation may even decide to outsource the internal audit of its accounting system (SAS 28.26). An external audit of the accounting system is a subsequent assessment of the integrity and accuracy of accounting data, specifically those included on the balance sheet, income statement, cash flow statement and other financial statements. External audits are carried out by certified auditors, i.e. public accountants, who operate beyond both the accounting department and the business organisation itself. Mandatory external audits of the financial statements of certain business organisations are stipulated by the law (SAS 28.34), usually within the framework of the law relating to undertakings. In Slovenia, all large and mediumsized $^{3}$ companies, and companies whose securities are quoted on the stock exchange, must have their annual financial statements audited in accordance with the Auditing Act within six months of the end of the business year, which may differ from the calendar year.

\section{Slovenian Accounting Standards ${ }^{4}$}

Slovenian Accounting Standards (SASs) are based on the Code and deal more precisely with accounting principles concerning the recording and processing of financial data, the formulating of financial information and both the presentation and maintenance of financial data and financial information. Financial information are disclosed by different reports, whereas financial statements are the principal means through which financial information is communicated to people outside the enterprise. If they are to serve their prime purpose, financial statements should be comprehensive, should present the essentials and should be reliable, while their comparability should be ensured. In order to satisfy these requirements, key accounting treatments should never be just left to the expertise and interests of an individual enterprise, but should rather be defined in detail by the profession. In Slovenia, this mission is carried out by the SASs.

3 Medium-sized companies are those which cannot be classified as small but which satisfy at least two of the following criteria (Companies Act 2006 (ZGD-1), Article 55):

- an average number of employees not in excess of 250

- net sales revenues below $€ 29200000$

- an asset total at the date of the balance sheet which is not in excess of $€ 14600000$.

A large company is one which exceeds at least two of the above criteria. In addition, all banks, insurance companies and companies required to produce consolidated financial statements are considered large.

4 This section is based on Slovenian Accounting Standards (2002 and 2006) and the Companies Act with Commentary (2002). 
SASs are aimed primarily at accounting operations in incorporated companies but they are, in fact, also used by other enterprises, non-profit institutions, other entities and government bodies in the scope that may be stipulated by relevant regulations. Furthermore, SASs represent a useful basis for taxation purposes although they do not directly deal with the process of the preparing and filling in of tax returns.

SASs were first issued in 1993. They were developed from the drafts of the Yugoslav standards of 1989 and completed before the passing of the first Slovenian Companies Act. ${ }^{5}$ In the meantime, the theory of accounting came on in leaps and bounds, and both the environment and the circumstances in which our business organisations had been operating underwent a considerable transformation: the rate of inflation was decreasing; Slovenia had opened up in political as well as economic terms, and had started the process of joining the European Union; there was greater exposure to the effects of globalisation, which gave rise to the push for the international harmonisation of accounting standards; etc. Thus, the revision of SASs was inevitable so, for the financial years beginning on or after 1 January 2002, new accounting standards (hereinafter: SASs 2002) came into force following the major amendments of the Companies Act which were the result of the project 'Harmonisation of the Slovenian Companies Act with EU legislation', sponsored by the PHARE programme, and following changes to International Accounting Standards.

With accession to the European Union, Slovenia had to adopt the European Union's legal framework, including the law relating to undertakings which, among various pieces of legislation, also comprises certain accounting directives: the Fourth Council Directive on the annual accounts of certain types of companies; the Seventh Council Directive on consolidated accounts; and Regulation (EC) No 1606/2002 on the application of international accounting standards issued by the International Accounting Standards Board (IASB). The new Slovenian Companies Act (ZGD-1), which again includes basic accounting provisions, provided the basis for the second amendment of Slovenian Accounting Standards (hereinafter: SASs 2006) which entered into force on 1 January $2006 .{ }^{6}$ However, it is still specific to SASs that they are not focused exclusively on the external financial reporting of past performance as, for example, are the International Financial Reporting Standards (IFRSs) issued by the IASB. SASs are based on the fundamental idea that external financial reporting should also have an impact on the fundamental accounting system, with specific solu-

5 The first 30 SASs were submitted for public debate in 1990 and 1991, and all the comments as well as proposals made at that time were incorporated into the final texts. The two following SASs were designed in 1992 and were discussed within the professional community until spring 1993 . The SAS Committee then submitted all 32 SASs as its own proposal which was then approved by the Professional Council of the Slovenian Institute of Auditors, which is authorised to adopt the standards. The SAS Committee has a chair and no less than six members, of which two must be university professors of accounting and auditing, and two must be practising accountants. For the drafting of an SAS, a threemember working group is appointed by the Committee. Once at least two-thirds of Committee members have approved the presented draft, it can be submitted to the professional community for public discussion that will last no less than three months.

6 Indeed, the relationship between law and accounting standards reflects very closely the extant position in the UK (Garrod and Turk, 1995: 755). 
tions provided for internal reporting. The detailed aspects of internal reporting are not elaborated in SASs since they largely depend on the needs and requirements of each specific business organisation.

SASs are, in the field of external financial reporting, almost completely harmonised with IFRS. In order to achieve this level of harmonisation, the profound amendment of SASs were needed in the following cases:

- property, plant and equipment - the introduction of a clear separation of cost model and a revaluation model for measurement after recognition

- investment property - separate accounting treatment, with the possibility of using a fair value model for measurement after recognition

- intangible assets - the introduction of a clear separation of cost model and a revaluation model for measurement after recognition; the prohibition of the amortisation of intangible assets with indefinite useful life

- financial assets - the introduction of four categories of financial assets (financial assets at fair value through profit and loss; available-for-sale financial assets; heldto-maturity investments; and loans and receivables) with different accounting treatment for measurement after recognition

- some changes in the balance sheet, income statement and cash flow statement.

The Appendix contains a list of the first 30 general core SASs.

\section{Conclusion}

This article has dealt with the role of accounting in business organisations and with the Slovenian concept of accounting, where accounting is not just a synonym for book-keeping, but contains all four accounting functions - i.e. book-keeping; budgeting; analysing; and supervision - and is a business organisation's central (financial) information centre.

Following this model, the accounting department should contain all these functions. However, in practice, the historical perception of the accounting function is simply one of book-keeping, with planning and analytical functions carried out separately and independently. Thus, we can notice the introduction of control departments, sometimes with simply re-named departments for planning and analysing, and the large-scale usage of the expressions of 'control' and 'controller', often in very different contexts.

These discrepancies arise because of two different approaches: the Anglo-American; and the German. The word 'controllership' which, in English, marks the range of assignments performed by a controller - i.e. in practice the duties of the chief (management) accountant - was, in the German language, replaced with the word 'control' which, in English, denotes the implementation of management control. However, in the German language, 'control' is used in two senses. The first is control as an institution, which marks the range of assignments which are actually performed by a controller in practice and is almost identical to the actual meaning of the English word 'controllership'. The second is control as a function or a process, which is jointly performed by controller(s) and manager(s) and is somehow more an academic construct which instructs what a controller should do.

So, controlling, in this our perspective, is a part of modern accounting and, therefore, the natural position of the control department lies within the accounting department. 


\section{References}

Accounting Principles Board (APB) (1970) APB Statement No. 4: Basic Concepts and Principles Underlying Financial Statements of Business Enterprise New York: AICPA.

Alexander, D and C. Nobes (2001) Financial Accounting - an International Introduction Harlow: Pearson Education Limited.

Atkinson, A. A, R. S. Kaplan and M. S. Young (2003): Management Accounting 4h $^{\text {th }}$ edition, Harlow: Pearson Education Limited.

Batchelor, A (1999): 'Is the balance sheet outdated?' Accountancy 123(1266): 81-83.

Companies Act with Commentary (2002) (Zakon o gospodarskih dru_bah (ZGD) s komentarjem published in Slovenian), Marjan Kocbek (ed.) Ljubljana: GV Založba.

Companies Act (2006) ('Zakon o gospodarskih dru_bah' (ZGD-1), published in Slovenian) (19 April 2006)

http://www.dz-rs.si/index.php?id=101\&st=a\&qsn=ZGD\&mandate=-1\&unid= $\underline{\text { SZIC12563A400338836C1257146005D7D98\&showdoc }=1)}$.

Drury, C (2000) Management \& Cost Accounting $5^{\text {th }}$ edition, London: Thomson Learning.

Garrod, N and I. Turk (1995) 'The development of accounting regulation in Slovenia' European Accounting Review 4(4): 749-764.

Horngren, C. T, A. Bhimani, S. M. Datar and G. Foster (2002): Management and Cost Accounting $2^{\text {nd }}$ edition, Harlow: Prentice Hall Europe.

International Accounting Standards Board (IASB) (2007) International Financial Reporting Standards (IFRSs) London: International Accounting Standards Committee Foundation.

Kieso, D. E, J. J. Weygandt and T. D. Warfield (2005): Intermediate Accounting $11^{\text {th }}$ edition, New York: John Wiley \& Sons Inc.

Prakash, P and A. Rappaport (1975): Informational interdependencies: system structure induced by accounting information Accounting Review Oct: 723-734.

Professional Council of the Slovenian Institute of Auditors (1998): Code of Accounting Principles (Kodeks računovodskih načel, published in Slovenian), Ljubljana: Association of Accountants, Treasurers and Auditors of Slovenia (Zveza računovodij, finančnikov in revizorjev Slovenije).

Raiborn, C. A, J. T. Barfield and M. R. Kinney (1999): Managerial Accounting $3^{\text {rd }}$ edition, Cincinnati: South-Western College Publishing.

Riahi-Belkaoui, A (2004): Accounting Theory $5^{\text {th }}$ edition, London: Thomson Learning.

Slovenian Institute of Auditors (2003): Slovenian Accounting Standards 2002 Ljubljana: Association of Accountants, Treasurers and Auditors of Slovenia.

Slovenian Institute of Auditors (2007): Slovenian Accounting Standards 2006 Ljubljana: Association of Accountants, Treasurers and Auditors of Slovenia. 
Turk, I (1997): 'From the idea of contemporary accounting in Slovenia to Slovenian accounting standards and auditing' (published in Slovenian) Naše gospodarstvo 43(5-6): 533-538.

Turk, I (2002): Dictionary of Accounting, Finance and Auditing (Pojmovnik računovodstva, financ in revizije, published in Slovenian) Ljubljana: Slovenian Institute of Auditors.

Turk, I and D. Melavc (2002): Accounting (Raèunovodstvo, published in Slovenian), Kranj: Založba Moderna organizacija.

Weygandt J. J, D. E. Kieso and P. D. Kimmel (2002): Principles of Financial Accounting $6^{\text {th }}$ edition, New York: John Wiley \& Sons Inc.

Willson, J. D and J. M. Roehl-Anderson (1999), in S. M. Bragg (1999): Controllership - The Work of the Managerial Accountant $6^{\text {th }}$ edition, New York: John Wiley \& Sons Inc.

\section{Appendix}

Here is a list of the first thirty general core SASs: ${ }^{7}$

SAS 1: Tangible Fixed Assets (Plant, Property and Equipment)

SAS 2: Intangible Assets and Long-term Deferred Costs

SAS 3: Investments

SAS 4: Inventories

SAS 5: Receivables

SAS 6: Investment Property

SAS 7: Cash

SAS 8: Equity Capital

SAS 9: Long-term Liabilities

SAS 10: Provisions and Long-term Deferred Revenues

SAS 11: Short-term Liabilities

SAS 12: Short-term Accrued and Deferred Items

7 These general core standards are followed by the special Standards which contain accounting solution for certain entities like banks (SAS 31, in force until 31 December 2005); insurance companies (SAS 32, in force until 31 December 2006); co-operatives (SAS 34); public enterprises (SAS 35); non-profit organisations (SAS 36); mutual funds (SAS 38); and sole proprietorships (SAS 39). Nevertheless, all SASs have the same structure. In the introductory chapter (A), each SAS refers to the relevant basis (the principles contained in the Code), followed by the substance of the issue that it covers; it then refers to the IASs or the other international frameworks that it takes into account as well as the other SASs to which it is related. It is necessary to stress that a certain SAS might relate to more than one IAS and that the substance of an IAS might be found in more than one of its Slovene counterparts. Subsequently, Chapter B contains the text of the SAS; Chapter $\mathrm{C}$ features the definitions of key terms used in the SAS; while Chapter D adds some more explanations. At the end, Chapter E shows the date on which the SAS was approved. 
SAS 13: Depreciation and Amortisation

SAS 14: Costs of Material and Services

SAS 15: Costs of Labour and other Employee Benefits

SAS 16: Costs in Terms of Types, Centres and Units

SAS 17: Expenses

SAS 18: Revenues

SAS 19: Types of Operating Result and Net Cash Flows

SAS 20: Budgeting and Budgets

SAS 21: Book-keeping Documents

SAS 22: Books of Account

SAS 23: Accounts Processing and Statement of Account

SAS 24: Formats of Balance Sheet for External Business Reporting

SAS 25: Formats of Income Statement for External Business Reporting

SAS 26: Formats of Cash Flow Statement for External Business Reporting

SAS 27: Formats of Statement of Changes in Equity Capital for External Business Reporting

SAS 28: Accounting Supervision

SAS 29: Accounting Analysing

SAS 30: Accounting Information Reporting.

We can notice that no adequate international standards exist for the issues dealt with by SASs Nos. 19 to 23 and 28 to 29 . 